\title{
Palaces, Itineraries and Political Order in the post-Carolingian Kingdoms
}

\author{
Simon MacLean \\ University of Saint Andrews
}

\section{Introduction}

In the middle of the 880s Notker, a monk from St-Gall in what is now Switzerland, wrote a highly anecdotal and mythologising biography of Charlemagne (768-814), several pages of which are devoted to descriptions of the emperor's reception of foreign embassies. ${ }^{1}$ These stories depicted the fear and respect supposedly accorded to Charlemagne by Byzantine and "Persian" (meaning Abbasid) legates who shivered before the great Frankish king and showered him with extravagant presents: "it seemed as if the East had been left bare so that the West might be filled", as Notker put it. ${ }^{2}$ The king's effortless superiority to his eastern counterparts plays out in the text through a number of sharpened motifs, including the etiquette of the hunt in addition to the formal exchange of gifts and the terrifying experience of the royal presence. But it is also noticeable that these encounters are projected by their author into the solid architectural setting of the great Carolingian palace at Aachen. The Byzantine envoys are led through a series of rooms in which they repeatedly mistake palace officials for the emperor before finally collapsing in awe before the glory of the real thing, standing before an open window at the heart of the complex. ${ }^{3}$ For the Abbasid embassy, meanwhile, the sickening realisation of Frankish superiority only hits home after they ascend the palace solarium from which they are able to look down upon the king's enormous entourage. ${ }^{4}$ The palace here was no mere backdrop but played an active role in the narrative. The monk of St-

\footnotetext{
${ }^{1}$ Notker, Gesta Karoli, ed. H. Haefele, MGH SRG NS 2.6-9 (Berlin: Weidmann, 1959), 53-65.

${ }^{2}$ Notker, Gesta Karoli, 2.8, 59, trans. D. Ganz, Two Lives of Charlemagne (London and New York: Penguin, 2008), 94.

${ }^{3}$ Further on Notker's depictions of palatial architecture see S. Airlie, "The Palace of Memory: the Carolingian Court as Political Centre", in Courts and Regions in Medieval Europe, ed. S.R. Jones, R. Marks and A.J. Minnis (York: York Medieval Press, 2000), 1-20, at 4-5.

${ }^{4}$ On the ideological significance of the solarium see M. de Jong, "Charlemagne's Balcony: the Solarium in Ninth-Century Narratives", in The Long Morning of Medieval Europe, ed. J.R. Davis and M. McCormick (Aldershot: Ashgate, 2008), 277-89.
} 
Gall's imagining of these encounters therefore serves to illustrate the significance of the "palatium" as a central symbol of Carolingian royal power writ large, for ideological statements about which it provided the essential setting.

Notker's unlikely depictions of Greeks and "Persians" represented a somewhat provincial and orientalising strand in the Western imagination, and in view of this it is perhaps ironic that his description of Charlemagne's palace (linked sequences of spaces used to control access to the ruler and emphasise his separateness) recalls less the open spaces of the real Aachen than the more intricate and intimidating layouts of the palace in Constantinople or Abbasid centres like Baghdad or Ukhaydin. ${ }^{5}$ But the concept of the palace as a metonym for royal or imperial power was not confined to the West. For example, the Abbasid historian Tabari (an exact contemporary of Notker's) collapsed his explanation of the waning of Sasanian power in the seventh century into an anecdote about the physical disintegration of Khusraw II's royal palace. ${ }^{6}$ The ubiquity of the royal palace as a political symbol as well as a physical structure, in the imagination as well as on the ground, is what makes it a useful "clue" for doing comparative history. As a specific category which overlaps different polities, it provides a hinge via which to consider questions of similarity and difference. ${ }^{7}$

I will attempt to return to such broader comparisons towards the end of this article, but my main aim is to discuss the representation of the palace as a tool for calibrating political change within the Frankish world, by comparing the ninth century with the tenth. The decades after the death of the last legitimate Carolingian emperor Charles III "the Fat" in 888 represented a moment of dramatic structural change in the Frankish world as the imperial landscape of the ninth century disintegrated and re-formed into the post-Carolingian world of the tenth; a shift from a large hegemonic empire ruled

\footnotetext{
${ }^{5}$ On these see e.g. R. Hillenbrand, Islamic Architecture: Form, Function and Meaning (Edinburgh: Edinburgh University Press, 1994), 392-5; H. Kennedy, The Court of the Caliphs (London: Weidenfeld \& Nicolson, 2004), 137-9; P. Magdalino, Studies on the History and Topography of Byzantine Constantinople (Aldershot: Ashgate, 2007). On Notker as orientaliser see C. Wickham, "Ninth-Century Byzantium Through Western Eyes", in Byzantium in the Ninth Century - Dead or Alive?, ed. L. Brubaker (Aldershot: Ashgate, 1998), 245-56, esp. 254-6.

${ }^{6}$ The History of Al-Tabari. Vol. V: The Sasanids, the Byzantines, the Lakhmids, and Yemen, trans. C.E. Bosworth (Albany: SUNY Press, 1999), 332-5.

${ }^{7}$ C. Wickham, Problems in Doing Comparative History: the 2004 Reuter Lecture (Southampton: University of Southampton, 2005), 10-15, for discussion of methodological issues and the concept of the "clue", which is in turn borrowed from C. Ginzburg, "Morelli, Freud and Sherlock Holmes", History Workshop Journal 9 (1980), 5-36.
} 
by members of a single dynasty to a jigsaw of smaller kingdoms controlled by new, unrelated and mutually antagonistic royal families. ${ }^{8}$ The change was noted by contemporaries such as Regino of Prüm, who wrote a famous description of these new rulers' inability to dominate each other, which "increased the discord among them" and "equipped them to destroy each other in the competition for power". 9

Yet the transition from Carolingian to post-Carolingian remains under-analysed, and tends to be absorbed into grander models of historical development, in particular those associated with debates concerning medieval Staatlichkeit ("state-ness") and the "feudal revolution" of the year 1000. ${ }^{10}$ These ways of framing the transition from the ninth-century world to that of the tenth can be rather polarising: 888 tends to appear in these debates either as a major turning-point (marking the end of Carolingian institutions and the inauguration of a new age of stateless, illiterate politics) or as a mere ripple barely disturbing the surface of deep continuities which persisted to the millennium or even beyond. But recent research has highlighted the ambiguities of the transition. On the one hand we see, $c$. 900, kings who were structurally weaker than their predecessors, who hardly ever legislated, who were often not succeeded by their sons, and whose deeds went largely unchronicled thanks to the sudden demise of a long and rich tradition of contemporary history which revolved around the deeds of rulers and thus articulated the thought-world of Carolingian politics; but on the other we see an increase in the consumption and adaptation of eighth- and ninth-century law (secular and ecclesiastical) and the reification of Carolingian definitions of office and property. ${ }^{11}$ The disintegration

\footnotetext{
${ }^{8}$ On this shift and its significance see above all S. Airlie "Les élites en 888 et après, ou comment pense-ton la crise carolingienne?", in Les Elites au Haut Moyen Age. Crises et Renouvellements, ed. F. Bougard, L. Feller and R. Le Jan (Turnhout: Brepols, 2006), 425-37; S. Airlie, "Sad Stories of the Death of Kings: Narrative Patterns and Structures of Authority in Regino of Prüm's Chronicon", in Narrative and History in the Early Medieval West, ed. E.M. Tyler and R. Balzaretti (Turnhout: Brepols, 2006), 105-31. Following Airlie, I use "post-Carolingian" to refer to the period after the end of Carolingian hegemony in 888 , even though some kings of this era were from the Carolingian family.

${ }^{9}$ Regino, Chronicle, ed. F. Kurze, Reginonis abbatis Prumiensis Chronicon cum continuatione Treverensi, MGH SRG (Hanover: Hahn, 1890), s.a. 888, 129.

${ }^{10}$ For the former see now Der frühmittelalterliche Staat-Europäische Perspektiven, ed. W. Pohl and V. Wieser (Vienna: Austrian Academy of Sciences, 2009); and for references on the latter see S. MacLean, “Apocalypse and Revolution: Europe around the Year 1000", Early Medieval Europe 15 (2007), 86-106. On the year 900 as a turning point, see R. Le Jan, "Le royaume franc vers 900: un pouvoir en mutation?", in Les Fondations scandinaves en Occident et les débuts du duché de Normandie, ed. P. Bauduin, (Publications du CRAHM: Caen, 2005), 83-95.

${ }^{11}$ Law: W. Hartmann, Kirche und Kirchenrecht um 900. Die Bedeutung der spätkarolingischen Zeit für Tradition und Innovation im kirchlichen Recht (Hanover: Hahnsche Buchhandlung, 2008). Office: S.
} 
of the Carolingian Empire, in other words, paradoxically coincided with the crystallisation of some of the pillars of Carolingian political order. ${ }^{12}$

Neither languid continuity nor rapid change therefore fully captures the messy implications of the Empire's end. The emergence of a new political order under the neoCarolingian hegemony of the Ottonians from the middle of the tenth century is well appreciated, but the indistinct texture of the in-between period $c .888-c .950$ has not yet been fully described. What did the same-but-different post-Carolingian kingdoms owe to their predecessors, and how should we characterise that debt if not in simple terms of continuity or change? Here, palaces are useful. Because Carolingian palaces continued to exist and to matter in post-Carolingian Europe, fixed in the same locations while the world dissolved and reconstituted itself around them, we can use them as wormholes taking us back and forth between the parallel universes of the ninth and tenth centuries.

\section{The fate of the Carolingian palatium}

My interest is more in representations than architecture, and my starting point is a straightforward question about terminology: what happened to the concept of the palatium after the end of the Empire in 888? The term itself was commonplace in Carolingian documents as a descriptor for royal residences, but after 888 it appears in many fewer documents and in relation to many fewer sites. There are two reasons why this is significant. The first is that, as Notker's stories suggested, during the ninth century the term "palatium" was not just a literal description of a type of building, but a core metaphor for Carolingian political order as a whole. Thus in the 830s, when a crisis at court provoked two major rebellions, critics of the regime attacked the sexual behaviour of the empress Judith as having created disorder in the Empire by polluting the "dignity" of the "palatium"; and it is no coincidence that the nearest thing we have to a treatise on

Patzold, Episcopus. Wissen über Bischöfe im Frankreich des späten 8. bis frühen 10. Jahrhunderts (Ostfildern: Thorbecke, 2008). Property: C. West, Reframing the Feudal Revolution : Political and Social Transformation between Marne and Moselle, c.800-c.1100 (Cambridge University Press : Cambridge, 2013). Legislation: S. MacLean, "Legislation and Politics in Late Carolingian Italy: the Ravenna Constitutions”, Early Medieval Europe 18 (2010), 394-416. The last major Carolingian history, Regino's Chronicle, ends in 906.

${ }^{12}$ For a stimulating discussion of this paradox see T. Riches, "The Changing Political Horizons of gesta episcoporum from the Ninth to the Eleventh Centuries", in Patterns of Episcopal Power: Bishops in Tenth and Eleventh Century Western Europe, ed. L. Körntgen and D. Waßenhoven (De Gruyter: Berlin, 2011), 51-62. 
Carolingian government is entitled De ordine palatii ("On the ordering of the palace"). ${ }^{13}$ These broader connotations were also in play when the word was attached to particular places in the enactment clauses of royal charters. These document show a variety of terms for individual residences (e.g. "curtis", "villa") which were not deployed with absolute consistency. But it has been demonstrated by Thomas Zotz that such terminology was intended to bear political meaning and was not deployed indiscriminately or interchangeably - royal charters were public documents whose superficially dry rhetorical formulas preserve for us the fossils of performed political discourses. ${ }^{14}$ Thus, for example, the court of Charles the Fat used the label "palatium" for only one residence in each of his kingdoms, self-consciously creating a different pattern from that found under his father and articulating a particular version of political geography. 15 "Palatium", then, was not an objective descriptive term for a particular kind of royal site, but an attribute of a residence's political significance - its ascribed centrality - at any given moment. The term is useful because it is a grounded fragment of political discourse and thus, to borrow the words of Clifford Geertz, "mark[s] the center as center and give[s] what goes on there its aura of being not merely important but in some odd fashion connected with the way the world is built." 16

The second reason is methodological. Isolating a term like "palatium" as it is used in royal charters, and building arguments on that basis, of course does not provide a

13 J.L. Nelson, "Kingship and Empire", in Carolingian Culture: Emulation and Innovation, ed. R. McKitterick (Cambridge: Cambridge University Press, 1994), 52-87, at 59; Airlie, "Palace of Memory", 78; M. de Jong, The Penitential State: Authority and Atonement in the Age of Louis the Pious, 814-840 (Cambridge: Cambridge University Press, 2009).

${ }^{14}$ T. Zotz, "Palatium publicum, nostrum, regium. Bemerkungen zur Königspfalz in der Karolingerzeit", in Die Pfalz. Probleme einer Begriffsgeschichte, ed. F. Staab (Speyer: Verlag der Pfälzischen Gesellschaft zur Förderung der Wissenschaften, 1990), 71-101; T. Zotz, "Palatium et curtis. Aspects de la terminologie palatiale au Moyen Age", in Palais royaux et princiers au Moyen Age, ed. A. Renoux (Le Mans: Publications de l'Université du Maine, 1996), 7-15. On charters see C. Insley, "Where did all the Charters go? Anglo-Saxon Charters and the New Politics of the Eleventh Century", Anglo-Norman Studies 24 (2002), 109-28; G. Koziol, The Politics of Memory and Identity in Carolingian Royal Diplomas: the West Frankish Kingdom (840-987) (Brepols: Turnhout, 2012).

${ }^{15}$ Elites accepted and adopted these definitions: for an example see Airlie, "Palace of Memory", 11.

${ }^{16}$ C. Geertz, "Centers, Kings and Charisma: Reflections on the Symbolics of Power", in C. Geertz, Local Knowledge: Further Essays in Interpretive Anthropology (New York: Basic Books, 1983), 121-46, at 124. See also E. Shils, "Centre and Periphery", in The Logic of Personal Knowledge: Essays Presented to Michael Polanyi (London: Routledge \& Kegan Paul, 1961), 117-30. On the term palatium as an aspect of political discourse in this context see T. Zotz, "Symbole der Königsmacht und Spiegel gesellschaftlicher Interaktion: zur Rede von palatium in den Urkunden der Ottonen", in Retour aux sources. Textes, études et documents d'histoire offerts à Michel Parisse, ed. S. Gouguenheim et al. (Paris: Picard Editions A. et J., 2004), 363-72, at 365. 
comprehensive picture of how "palaces" were used or perceived. But focusing on one class of source (which in any case provides the great majority of the evidence) is what permits comparison. And although we find fewer residences labelled as "palatium" in tenth-century royal charters than ninth-, we have an increasing number of such documents overall (at least for Germany and Italy). The formal structure and political idioms of these charters - a very conservative genre - were largely the same as in the Carolingian period, and the full semantic range of the "palatium" concept is visible in the tenth-century sources. ${ }^{17}$ Nor, since the overall trend is so clear, can we dismiss the change in usage as a result of scribal whim, though that must have been a factor on occasion. ${ }^{18}$ What is more, tenth-century narrative sources also tend to use the term "palatium" much less frequently than their Carolingian predecessors, and for the same small group of residences. ${ }^{19}$ In other words, at the level of the big picture, the changing application of this terminology is a real change, not an effect of the evidence.

Considering the shifting use of this core political metaphor allows us to think about changing perceptions of the royal palace and of political geography, an aspect which has not been fully considered amidst the voluminous research on more practical aspects of the early medieval palace system. ${ }^{20}$ This article is therefore more concerned with how contemporaries imagined and categorised certain royal sites than with their operation as political centres. That said, we must keep in mind that the terminology of our sources is not separate from the social and political world to which it refers. ${ }^{21} \mathrm{I}$ propose therefore to interpret the labels attached to particular places as arguments about the political significance of those places - as constituting rather than simply revealing their character. The word "palatium" both clings to specific places and points outwards to contemporary conceptions of the realm - by following it like a trail of breadcrumbs

\footnotetext{
${ }^{17}$ As demonstrated by Zotz, "Symbole der Königsmacht".

${ }^{18}$ F. Bougard, "Palais princiers, royaux et imperiaux de l'Italie carolingienne et ottonienne", in Palais royaux, ed. Renoux, 181-96, at 183-4, for one example of scribal preference apparently playing a part.

${ }^{19}$ G. Streich, "Palatium als Ordnungsbegriff und Ehrentitel für die Urkundungsorte der deutschen Könige und Kaiser im Hochmittelalter", in Die Pfalz, ed. Staab, 103-29, at 107.

${ }^{20}$ As pointed out by T. Reuter, "Regemque, quem in Francia pene perdidit, in patria magnifice recepit: Ottonian Ruler Representation in Synchronic and Diachronic Comparison", in T. Reuter, Medieval Polities and Modern Mentalities, ed. J.L. Nelson (Cambridge: Cambridge University Press, 2006), 127-46, at 130.

${ }^{21}$ M. Innes, "People, Places and Power in the Carolingian World: a Microcosm", in Topographies of Power in the Early Middle Ages, ed. M. de Jong and F. Theuws (Leiden, Boston and Cologne: Brill, 2001), $397-$ 437, at 398-9.
} 
through the forests of early tenth-century history, we can observe changes in the symbols of political order and perceptions of political geography. ${ }^{22}$

The dwindling attribution of the term "palatium" to royal residences is observable in all three of the major regions of the old empire - west Francia, east Francia and Italy. In west Francia, the term, though common enough up until the end of the Empire, barely appears in royal charters between the reign of the first non-Carolingian king Odo (888898 ) and that of the last genuinely powerful Carolingian Lothar (954-86). The one very striking exception is the reign of Charles III "the Simple" (or Straightforward) (899-923), during which the term was used frequently, even aggressively. Nine residences are labelled "palatium" by Charles's scribes, most frequently Compiègne, which is so called no fewer than twenty-one times. This serves to throw the general trend into even sharper focus: of Charles's four successors, only the chancery of his son Louis IV (936-54) used the label at all, and then only twice (once for Compiègne, once for Rheims). In Italy, the term went from being commonly used under Lothar (840-55) and Louis II (855-75), to being extremely scarce during the first half of the tenth century, and applied to a much restricted group of residences - for about twenty years after 885 , not even the main royal centre of Pavia was distinguished with the category of "palatium". ${ }^{23}$ And in the eastern kingdom, ruled from 919 by the Ottonian family, palatial status was reserved above all for key sites in the far west of the realm, that is Lotharingia, Alsace and the middle Rhine valley. By the end of the tenth century, only Aachen and Ingelheim had been given the title with anything approaching consistency, followed by Frankfurt, Cologne and Erstein - all five lie on or west of the Rhine. ${ }^{24}$

This pattern has been described before, but not fully explained. Zotz recognised this in an excellent discussion of the Ottonian evidence and convincingly argued that palatial vocabulary, redolent of Carolingian tradition, was deployed to enhance particular acts of royal self-representation. ${ }^{25}$ But the pattern as a whole has generally been seen as the product of a long-term process by which royal office itself became institutionalised, or transpersonalised. The culmination of this process is held to be visible in Wipo's mid-

${ }^{22}$ On the link between space and power see M. Mann, The Sources of Social Power. Vol. I: A History of Power from the Beginning to AD 1760 (Cambridge: Cambridge University Press, 1986), 9.

${ }^{23}$ The rise and fall of this vocabulary in Italy is comprehensively described by Bougard, "Palais princiers".

${ }^{24}$ Streich, "Palatium als Ordnungsbegriff", 103-7. The exception was Magdeburg, on which see below.

${ }^{25}$ Zotz, "Symbole der Königsmacht". 
eleventh century biography of the emperor Conrad II, which includes a famous account of the destruction of the royal palace at Pavia in $1024 .{ }^{26}$ According to Wipo, the citizens responsible defended their actions by claiming that the fact they had acted after the death of Conrad's predecessor Henry II, but before the new ruler had been formally inaugurated, meant that there was no king and that the royal palace was at that point no more than a building. Conrad's counter-argument, that the kingdom persisted even after a king had died, and that its palaces were therefore permanently royal and public, is often considered to reveal a newly institutionalised conception of political power. ${ }^{27}$ With Wipo's anecdote in mind, the relatively consistent tenth-century attribution of palatial status to centres like Aachen and Pavia has been interpreted as representing an early stage of the move towards transpersonalisation, reflecting a growing sense that particular sites had the character of permanent royal centres. ${ }^{28}$

But the arguments reportedly rehearsed by Conrad and the Pavians in 1024 were not necessarily all that new, and indeed seem to be anticipated in an equally well-known ninth-century text, a rebuke issued to King Louis the German by Archbishop Hincmar of Rheims in 858. The thrust of Hincmar's put-down was that just because Louis, who had invaded the west Frankish kingdom, was staying in the royal residence of Attigny, that did not mean that he was in a royal palace - the palatium was a community of people and a political ideal, not a physical structure. ${ }^{29}$ The position against which the archbishop implicitly argued (and which was presumably adhered to by Louis and his entourage) was that palaces like Attigny were inherently royal, and that their possession amounted to a claim to exercise legitimate royal power - a position not so different from that ascribed by Wipo to Conrad II almost two centuries later. Comparing Hincmar and Wipo therefore

${ }^{26}$ Wipo, Gesta Chunoradi II, ed. H. Bresslau, MGH SRG (Hanover and Leipzig, 1915), c. 7, 29-30.

27 H. Wolfram, Conrad II, 990-1039: Emperor of Three Kingdoms, trans. D. Kaiser (Philadelphia: University of Pennsylvania Press, 2006), 63-4. The classic statement is H. Beumann, "Zur Entwicklung transpersonaler Staatsvorstellungen", in Vorträge und Forschungen 3 (1956), 185-224.

${ }^{28}$ See for example Streich, "Palatium als Ordnungsbegriff”, 109; Zotz, "Palatium publicum", 86, 90-1, 99; T. Zotz, "Grundlagen, Grenzen und Probleme der Staatlichkeit im frühen Mittelalter. Zur Bedeutung und Funktion der Königspfalzen", in Der frühmittelalterliche Staat, ed. Pohl and Wieser, 515-20. For an acute critique of the prevailing interpretation of Wipo see W. Pohl, "Staat und Herrschaft im Frühmittelalter: Überlegungen zum Forschungsstand”, in Staat im frühen Mittelalter, ed. S. Airlie, W. Pohl and H. Reimitz (Vienna: Austrian Academy of Sciences, 2006), 9-38, at 34.

${ }^{29}$ Die Konzilien der karolingischen Teilreiche 843-859, ed. W. Hartmann, MGH Concilia III (Hanover:

Hahnsche Buchhandlung, 1984), no. 41, c. 5, 412. Discussion: J. Fried, "Der karolingische Herrschaftsverband im 9. Jh. zwischen 'Kirche' und 'Königshaus'”, Historische Zeitschrift 235 (1982), 143, esp. 39-41; Zotz, "Palatium et curtis", 7-8. 
suggests that competing definitions of the palace and its relationship to the kingdom always co-existed, finding expression and meaning in particular political situations. This in turn calls into question the idea that the transpersonalisation of royal office, and of the palace, was a continuous and evolutionary process: the royalness of royal palaces was a recurring contemporary debate, not an independent variable which we can isolate and measure. ${ }^{30}$ We need to look more closely at the tenth-century evidence and ask what was specific about the circumstances that produced it, rather than invoking the explanatory power of a spectral historical process.

Perhaps the most obvious, and important, point to be made about the pattern of the evidence is that almost all the sites which retained the label palatium in the first half of the tenth century were closely associated with the ninth-century Carolingian dynasty, and especially with those rulers whose legacy was most keenly felt in the successor kingdoms, namely Charlemagne, Louis the German and Charles the Bald (particularly associated with Aachen, Frankfurt and Compiègne respectively). ${ }^{31}$ As Zotz persuasively argued, the attribution of the tag to these places can be read on one level as a straightforward attempt by new dynasties like the Ottonians to legitimise themselves through appeal to the Carolingian past. But despite the regularly expressed notion that the hallmark of the Ottonian age was the dynasty's inclination for building "new beginnings on Carolingian traditions", the Frankish past was not a straightforward resource for the Ottonian kings. ${ }^{32}$ The dynasty did not, for instance, directly imitate Carolingian royal titulature, and their origins in Saxony, on the far eastern frontier of the old empire, meant that their familiarity with Frankish kingship and their awareness of the ninth-century past may have been somewhat vague, and at any rate less clear than our own. ${ }^{33}$

\footnotetext{
${ }^{30}$ On the rhetoric of royalness that surrounded palatial space see also Stuart Airlie's article in this volume, above.

${ }^{31}$ On these rulers' associations with such palaces, denoted not least by their classification as palatia in royal charters, see C. Brühl, Fodrum, gistum, servitium regis: Studien zu den wirtschaftlichen Grundlagen des Königtums im Frankenreich und in den fränkischen Nachfolgestaaten Deutschland, Frankreich und Italien vom 6. bis zur Mitte des 14. Jahrhunderts (Cologne and Graz: Böhlau Verlag, 1968), 40-2; Zotz, "Palatium publicum", 91-5.

${ }^{32}$ Quote from Zotz, "Symbole der Königsmacht", 372.

33 Titles: E. Müller-Mertens, "Frankenreich oder Nicht-Frankenreich? Überlegungen zum Reich der Ottonen anhand des Herrschertitels und der politischen Struktur des Reiches", in Beiträge zur mittelalterlichen Reichs- und Nationsbildung in Deutschland und Frankreich, ed. C. Brühl and B. Schneidmüller (Munich: Oldenbourg, 1997), 45-52. Knowledge of the past: Reuter, "Regemque", 135-7; T. Reuter, "The Ottonians and Carolingian Tradition", in Reuter, Medieval Polities, 268-83.
} 
What is more, the relevance of Carolingian political geography to all the rulers of this generation was complicated by a history of rupture and discontinuity. The really iconic Carolingian palaces of the ninth century (those most often labelled "palatium" in the tenth) lay in royal heartlands that the post-888 kings could not control, and these residences thus lost their effective political centrality. This is perhaps easiest to see in west Francia, where the first post-Carolingian king Odo sought to rule in the fashion of his predecessors, as advertised by his coronation at Charles the Bald's palace of Compiègne in 888 . Thereafter, however, he found his itinerary restricted to points further west, nearer the heartlands of his family's own power in Neustria - his favoured sites included Paris, Orléans and Chartres, none of which had been significant royal centres of in the heyday of the Carolingians. ${ }^{34}$ This disjuncture between political tradition and political geography in Odo's reign contrasts with the promiscuous use of the term "palatium" for classical Carolingian centres, particularly Compiègne, in the reign of his rival and successor Charles the Simple (or Straightforward) - Charles, who was a Carolingian, had to assert continuity with his family's past so overtly precisely because it had become obvious that this continuity had been broken. ${ }^{35}$ Charles's successors Raoul and Louis IV (whose power bases lay in Burgundy and Laon respectively) were, like Odo, unable to lay claim to the residences east of the Seine that defined the old core of the west Frankish realm, and found themselves engaged in endless struggles for influence there with their powerful magnates. These observations could be broadly extended, with the necessary modifications, to east Francia and Italy.

To put it another way, the patterns of politics in the ninth century involved kings ruling from royal heartlands and struggling to keep control of their kingdoms' peripheries; while in the tenth, we see the dynamic inverted as new rulers from the edges of the old kingdoms (Saxony; Neustria and Burgundy; and in Italy Friuli and Spoleto) competed to regain control of the former Carolingian heartlands. The new dynasties could not, as is often stated, simply inherit Carolingian resources in these heartlands, for

\footnotetext{
${ }^{34}$ The evidence is summarised by R.H. Bautier, "Les itineraires des souverains et les palais royaux en France occidentale de 877 à 936", in Palais royaux, ed. Renoux, 99-110.

${ }^{35}$ On Charles's ostentatious appropriation of Carolingian tradition see B. Schneidmüller, Karolingische Tradition und frühes französisches Königtum: Untersuchungen zur Herrschaftslegitimation der westfränkisch-französischen Monarchie im 10. Jahrhundert (Wiesbaden: Franz Steiner Verlag, 1979); Koziol, Politics of Memory, 459-555.
} 
the notion of crown property was itself not clearly institutionalised. Instead, they needed to assert their claims to these resources and the territories in which they lay, and this gives us an alternative way to understand the use of the label "palatium" in this period as representing an argument (performed live to local audiences and fossilised in our documents) that these residences, which were symbolically important but lay in territories on the fringes of rulers' power, were inherently royal and should thus be associated with the king, as it were ex officio. Behind them we can perhaps infer a position being taken about the inherent royalty of certain places not dissimilar to those we inferred in the minds of Louis the German in 858 and Conrad II in 1024, both of whom were at those moments attempting - like the early Ottonians - to take control of territories where they were unsure of recognition. In the context of a fluid and competitive dynastic situation these labels, and the political performances that produced them, can therefore be read as assertions of continuity and stability, rather than as evidence of continuity itself. Here, in other words, we might do better to think of institutionalisation as an argument - and as an unintended consequence of political insecurity - rather than a process. ${ }^{36}$

Another distinctive feature of the immediately post-Carolingian world is the tendency of royal palaces to pass into the hands of queens. Perhaps the best-known example of this is the Saxon royal centre at Magdeburg, Otto I's favourite residence, which was established on the dower property of his first wife Edith. ${ }^{37}$ Already in 907 Charles the Simple had given to his wife Frederun two old Carolingian palaces, Ponthion and Corbeny, both referred to as palatium in his charters. ${ }^{38}$ These seem later to have been held by some of Frederun's successors as queens, as were other palatia at Attigny, Douzy and Meersen. ${ }^{39}$ We see a similar pattern south of the Alps: of the eight rural residences regarded as palatia in Italian royal charters of the ninth century, no fewer than five were

\footnotetext{
${ }^{36}$ On institutionalisation as a by-product of social relations, rather than their goal, see Mann, Sources of Social Power I, 14-16, 34-40. On the link between charters and performances, see now Koziol, Politics of Memory.

${ }^{37}$ Die Urkunden Konrad I., Heinrich I. und Otto I., ed. T. Sickel, MGH Diplomata regum et imperatorum Germaniae 1 (Hanover: Hahn, 1879-84), Otto I no. 14. Erstein had also been founded by a Carolingian queen and was thereafter associated with royal women.

${ }^{38}$ Recueil des actes de Charles III le Simple, roi de France, ed. P.Lauer (Paris: Académie des Inscriptions et Belles-Lettres, 1940), no. 56.

${ }^{39}$ For references and discussion see S. MacLean, "Making a Difference in Tenth-Century Politics: King Athelstan's Sisters and Frankish Queenship", in Frankland: the Franks and the World of the Early Middle Ages. Essays in Honour of Dame Jinty Nelson, ed. P. Fouracre and D. Ganz (Manchester: Manchester University Press, 2008), 167-90, at 183.
} 
in the hands of royal women by the middle of the tenth. ${ }^{40}$ This is a little-noticed but distinctive phenomenon of the tenth century: ninth-century queens were never given palaces as dowers and were characterised as guardians of the honestas of the palatium in the figurative sense, not as actual proprietors of individual residences. ${ }^{41}$ Part of the explanation for this shift is an attempt by weak tenth-century kings to incorporate their wives, who were often non-native, into the political life of their kingdoms by endowing (and empowering) them with resonant royal sites. ${ }^{42}$ But it could also be seen as another strategy employed by rulers of this period to strengthen their grip on such sites and bring them into a more formal relationship with their dynasties: queens often held the same properties in sequence. The association of palaces with queens was legitimised by Carolingian discourse on royal women: De ordine palatii, for example, characterised the queen as responsible for the provisioning of the royal palace. ${ }^{43} \mathrm{We}$ might also see the trend as linked to the tenth-century emphasis on dynastic commemoration as a key function of royal women. Although such acts of memoria are usually associated with royal nunneries, Stuart Airlie has emphasised that early medieval palaces were also important sites of political memory. ${ }^{44}$ Possession of these sites may thus have been considered a natural extension of queens' commemorative role.

Palaces were not the only sorts of site onto which value-judgements were projected in the tenth century. The other side of the coin can be seen in contemporary statements about the negative characteristics of certain locations: a well-known example is a reference to Saalfeld as a "place of evil counsel". 45 Perhaps a more intensely politicised sense of topography derived from the smaller stages on which tenth-century elite politics played out, and from the relatively restricted landownership of dynasties like

\footnotetext{
40 The Italian evidence is gathered by Bougard, "Palais princiers", 190-4.

41 Above, n. 13.

42 This is the argument of MacLean, "Making a Difference", which draws on the insights of P. Stafford, “Cherchez la femme. Queens, Queens' Lands and Nunneries: Missing Links in the Foundation of Reading Abbey", History 85 (2000), 4-27.

${ }^{43}$ Hincmar, De ordine palatii, ed. T. Gross and R. Schieffer, MGH Fontes (Hanover: Hahn, 1980), c. 22, $72-5$.

${ }^{44} \mathrm{~S}$. Airlie, "Palace of Memory", 12-14. On Ottonian queens and commemoration see P. Corbet, Les saints ottoniens: sainteté dynastique, sainteté royale et sainteté féminine autour de l'an mil (Sigmaringen: J. Thorbecke, 1986).

${ }^{45}$ Breisach had a similar reputation: Widukind of Corvey, Rerum Gestarum Saxonicarum Libri Tres, ed. P. Hirsch, MGH SRG (Hanover: Hahnische Verlag, 1935), 3.9, 109; Adalbert, Continuatio, ed. Kurze, Reginonis abbatis Prumiensis Chronicon MGH SRG (Hannover: Hahn, 1890), s.a. 953, 167.
} 
the Ottonians compared to their predecessors. But more generally the reification of particular palaces as possessing "palatial" attributes, or as having particular associations with royal women, can be seen as complementary strategies in the new dynastic environment of post-Carolingian Europe in which power politics was no longer a matter of competition between members of a single royal family fighting over the distribution of land and seniority, but between a number of families who were competing to appropriate the very notion of royalty itself. And royalty, in this context, remained virtually synonymous with Carolingian royalty, which is the notion that these kings tried to instrumentalise through ostentatious appropriation of Carolingian centres at the very fingertips of their reach.

The limits to the ability of even the Ottonians to domesticate this notion is indicated by the history of Otto I's favourite palace at Magdeburg in Saxony. This was the only place not in the far west of his realm dignified regularly with the label "palatium", but the designation did not stick and the transformation of Magdeburg into an archbishopric in 968 changed it into a completely different kind of centre. Although Magdeburg and its western counterpart Rheims were in practice the key political centres of their respective kingdoms, their different histories and their ecclesiastical nature precluded lasting characterisations of them as palatia. ${ }^{46}$ Otto certainly controlled Magdeburg, unlike the Carolingian residences in the far west of his kingdom, and classification of such personal sites as palaces was typical of the way that late Carolingian kings like Charles the Fat had defined their realms. But the impermanence of Magdeburg's status as a "palatium" suggests that its roots were not deep enough for it to be fully accepted as part of the "centre of the order of symbols, values and beliefs." 47 Recycling Carolingian palatial traditions was not a straightforward business for nonCarolingian kings, because such traditions were not simply found hanging in the air they had to be located, and performed, in particular places. ${ }^{48}$

\footnotetext{
${ }^{46}$ Recueil des actes de Louis IV, roi de France (936-954),ed. P. Lauer (Paris: Klincksieck, 1914), no. 42 features the only appearance of Rheims as "palatium".

${ }^{47}$ Shils, "Centre and Periphery", 117.

${ }^{48}$ By contrast, note the correlation of place, date, purpose and vocabulary in Recueil des actes de Louis IV, no. 4, which heralds Louis IV's renunciation of his protector Hugh the Great via pointed advertising of Carolingian traditions: promulgation on Christmas Day (the anniversary of Charlemagne's imperial coronation), at his father's great palace of Compiègne, which is give the attribute "palatium" (one of only two such uses in this king's charters).
} 


\section{Aachen as a place of conflict}

These arguments about the instrumentalisation of Carolingian discourses can be approached from another angle if we turn to look at the history of a single palace. The great palace of Aachen in northern Lotharingia is the best-documented of all Carolingian centres and its role has been intensively studied for the period c. 790-840, when it was the main residence of the emperors Charlemagne and Louis the Pious, and for the later tenth and eleventh centuries, when it was revived as an active political centre under Otto III and had its links to the royal chapel institutionalised. ${ }^{49}$ But its position in the Frankish kingdoms between these two high points is less fully appreciated. ${ }^{50}$ Historians tend to assume that Aachen had a more or less continuous history as a political centre which survived the collapse of the empire and was effortlessly inherited by the Ottonians - a conclusion seemingly supported by the fact that Otto I was crowned king at Aachen in 936, observing, according to Widukind of Corvey, Frankish tradition. ${ }^{51}$ Following the ground-breaking study of Otto's itinerary by Eckhard Müller-Mertens, the palace is regarded as having been absorbed seamlessly into the political structures of the Ottonian polity as the focal point of one of the three royal heartlands of the tenth-century realm (along with southern Saxony and the middle Rhine valley). ${ }^{52}$ Moreover, Aachen was the residence most often favoured with the title "palatium" in Ottonian charters. But we have already seen that the patterns of Carolingian geography were disrupted at the end of the

\footnotetext{
${ }^{49}$ For example: L. Falkenstein, Karl der Grosse und die Entstehung des Aachener Marienstiftes (Paderborn: Schöningh, 1981); L. Falkenstein, Otto III. und Aachen (Hanover: Hahn, 1998); J.L. Nelson, "Aachen as a Place of Power", in Topographies of Power, ed. de Jong and Theuws, 217-41; C. Bayer, "Die Aachener Marienkirche in der Diözese Lüttich: zu Funktionen, zur rechtlichen Stellung und zur Stiftsverfassung. Eine Skizze", in Dombaumeistertagung, ed. H. Maintz (Aachen: Mainz, 2010), 55-74. In the twelfth century Aachen was regarded as a coronation palace, and thus played a significant role in the conception of Hohenstaufen kingdom even though rulers rarely went there: C. Brühl, "Remarques sur les notions de "capitale" et de "residence" pendant le haut Moyen Age", Journal des savants 4 (1967), 193215 , at 208.

${ }^{50}$ Though see K. Hauck, "Die Ottonen und Aachen, 876 bis 936", in Karl der Große. Lebenswerk und Nachleben, vol. 4, ed. W. Braunfels and P.E. Schramm (Düsseldorf: Schwann, 1967), 39-53; and Falkenstein, Otto III. und Aachen, 2-17.

${ }^{51}$ Widukind, Rerum Gestarum Saxonicarum Libri Tres, 2.1, 63-6.

${ }^{52}$ E. Müller-Mertens, Die Reichsstruktur im Spiegel der Herrschaftspraxis Ottos des Großen (Berlin: Akademie-Verlag, 1980). For useful summaries of this work's main points see J. Bernhardt, Itinerant Kingship and Royal Monasteries in Early Medieval Germany, c. 936-1075 (Cambridge: Cambridge University Press, 1993), 60-70; E. Müller-Mertens, "Verfassung des Reiches, Reichsstruktur und Herrschaftspraxis unter Otto dem Großen", in Otto der Grosse: Magdeburg und Europa, ed. M. Pühle (Mainz: Philipp von Zabern, 2001), 189-98.
} 
ninth century - how can such discontinuities be incorporated into our understanding of the palace's history? First we will look briefly at how Aachen was thought about; and then how it was used.

The meaning of places is constructed not just through classification, but also by the stories told about them. ${ }^{53}$ Such narratives as we have underline the sense that the late ninth century witnessed a rupture in Aachen's history of centrality, and that contemporaries recognised this rupture as such. The real turning point was a Viking raid in 881 , in the course of which the attackers sacked and burned the great palace and (according to an annalist writing in Mainz) "used the king's chapel as a stable for their horses. " ${ }^{, 54}$ The significance of this attack should not be underestimated, for Aachen more or less drops out of our narrative sources after this point. ${ }^{55}$ Contemporary interpretations of the attack seem to indicate a sense of finality. In describing the 881 raid, led by a warlord called Godafrid [III], the Mainz annalist may have been tacitly responding to a story in Einhard's Life of Charlemagne in which an earlier Godafrid [I] threatened to bring a large army to Aachen and destroy it. ${ }^{56}$ Connoisseurs of Einhard, among whom we may number our annalist, could have read the reference to the stabling of enemy horses in Charlemagne's chapel as a belated consummation of this threat. ${ }^{57}$ Certainly, there are hints that this was the way it was understood by Notker of St-Gall, who collapsed together details from the careers of the two Godafrids to suggest that the same man who had boasted about destroying Aachen had also been active in the vicinity of the palace, even though the historical Godafrid I had never been near the region. ${ }^{58}$ Elsewhere in his work Notker hangs his sense of foreboding about the future of the Carolingian dynasty on a portentous comment about a wondrous Byzantine organ possessed by Charlemagne and widely regarded as a symbol of his prestige: "I must not, here and now, speak of where it

53 P. Smith, "The Elementary Forms of Place and their Transformations: a Durkheimian Model", Qualitative Sociology 22 (1999), 13-36, esp. 15-16; T. Gieryn, "A Space for Place in Sociology", Annual Review of Sociology 26 (2000), 463-96, esp. 465. On the role of texts and practices in constituting the meanings of places see also the article by Nadia El Cheikh in this volume, below.

${ }^{54}$ Annales Fuldenses, ed. F. Kurze, MGH SRG (Hanover: Hahn, 1891), s.a. 881, 97.

${ }^{55}$ Nelson, "Aachen as a Place of Power", 234.

${ }_{57}^{56}$ Einhard, Vita Karoli Magni, ed. O. Holder-Egger, MGH SRG (Hanover: Hahn, 1911), c. 14, 17.

${ }^{57}$ Annales Fuldenses, s.a. 874, 82 suggests that the Mainz author was familiar with Einhard's works.

${ }^{58}$ Notker, Gesta Karoli, 2.13,75-6; S. MacLean, Kingship and Politics in the Late Ninth Century: Charles the Fat and the End of the Carolingian Empire (Cambridge: Cambridge University Press, 2003), 203, 213 15. 
was set up, and how long it lasted, and how it perished at the same time as other losses." ${ }^{, 59}$ This veiled reference to the events of 881 captures the finality associated by contemporaries with the sack of Aachen.

Yet the moment when Aachen's political centrality was felt to have been brought to a violent end was precisely the same moment when its status as a numinous symbol for political order began to inflate. Late ninth-century accounts of Charlemagne's life project an aura not just around the great emperor's person, but around his most famous palace. Aachen appears much more often, and with more florid adjectives, in the Saxon Poet's early 890 s rewriting of Einhard's text than in the original. ${ }^{60}$ Notker's numerous Aachen stories likewise embellished the mystery and significance of the palace well beyond the descriptions in Einhard, also his main source, and even suggested that the palace's meaning had changed. Einhard had claimed that Charlemagne chose the site of Aachen because of its natural springs, and said that he liked to bathe in the company of numerous friends and courtiers; this is an image of Romanitas, recalling not only Suetonius's Lives of the Twelve Caesars but also Theophanes's account of the habits of the eighth-century Byzantine emperor Philippikos in the great imperial capital of Constantinople. ${ }^{61}$ But in Notker's hands the baths were transformed from a microcosm of Late Antique civilisation into a potent universal religious symbol, likened to baptismal waters in which even the Devil himself could be bested by righteous Carolingian rulers. ${ }^{62}$

This Aachen of the imagination (Notker confessed he had never been there) was a powerful symbol despite, or perhaps because of, the fact that it was no longer a living seat of power. No king visited Charlemagne's old palace between 877 and 900, and there are only four recorded visits in the three decades after that. ${ }^{63}$ Kings were not infrequently in the area, but usually preferred to stay at Herstal or Cologne rather than Aachen. The reason for this seems to have been that it lay on the very fringes or indeed beyond the

\footnotetext{
${ }^{59}$ Notker, Gesta Karoli, 2.7, 58; trans. Ganz, Two Lives, p. 92.

${ }^{60}$ Poeta Saxo, Annalium de gestis Caroli Magni Imperatoris Libri Quinque, ed. P. von Winterfeld, MGH Poetae 4.1 (Berlin: Weidmann, 1909), 29, 36-40, 43-4, 47, 49-50, 55, 63, 65, 69-70.

${ }^{61}$ Einhard, Vita Karoli, c. 22, 27; The Chronicle of Theophanes Confessor, trans. C. Mango and R. Scott, with G. Greatrex (Oxford: Oxford University Press, 1997), s.a. 713, 533: “...the emperor decided to make on the Saturday of Pentecost an entry on horseback, to bathe in the public baths of Zeuxippos and to lunch with citizens of ancient lineage." On the relationship to Suetonius: Nelson, "Aachen as a Place of Power", 236.

${ }^{62}$ Notker, Gesta Karoli, 2.15, 80; Nelson, “Aachen as a Place of Power”, 234-6.

${ }^{63}$ Falkenstein, Otto III. und Aachen, 2-21.
} 
control of these rulers. The limits of Charles the Simple's influence, for example, is clear from an incident in 920 when the Aachen treasury was emptied out by local aristocrats opposing the king in a struggle for control of the bishopric of Liège. ${ }^{64}$

Rulers instead sought to associate themselves with these narratives remotely. Thus in early 877, the same year in which the last ruling king for a generation visited Aachen, Charles the Bald unveiled his new chapel at Compiègne which was explicitly intended to recall Charlemagne's great residence. ${ }^{65}$ Charles the Fat's palace at Sélestat in Alsace, which probably dates from the early 880s, also featured architectural quotations of Aachen. ${ }^{66}$ This Charles's credentials as a connoisseur of Aachen's meanings are clear: in 881 after the Viking raid he had the palace's relic collection brought to his court in Alemannia; and he was also the intended recipient of the Charlemagne biography by Notker, whom he knew personally and whose tastes and interests the monk had in mind when he wrote. ${ }^{67}$ It is also interesting that Charles's only charter in favour of the royal chapel at Aachen, which probably dates from 884, was issued while he was resident at Regensburg, a palace with a chapel modelled on Aachen's. ${ }^{68}$ Similarly, Charles the Simple's only visit to Aachen, in 917, is known from the elaborately-worded gifts he made on that occasion to the chapel at his own favoured palace of Compiègne, itself (as already noted) a kind of copy of Aachen. ${ }^{69}$ This sort of "inter-palace dialogue" underlines the way that kings of this period tried to conjure a grid of royal centres that covered their

\footnotetext{
${ }^{64}$ Karoli III. capitula de Tungrensi episcopatu proposita, ed. A. Boretius and V. Krause, MGH Capitularia II (Hanover, 1897), no. 290, 380.

${ }^{65}$ Recueil des actes de Charles II le Chauve, roi de France, ed. G. Tessier et al. (Paris: Imprimérie Nationale, 1943-55), no. 425; J.L. Nelson, Charles the Bald (London: Longman, 1992), 247-8; Airlie, "Palace of Memory", 14-16.

${ }^{66}$ T. Zotz, "Carolingian Tradition and Ottonian-Salian Innovation: Comparative Perspectives on Palatine Policy in the Empire", in Kings and Kingship in Medieval Europe, ed. A.J. Duggan (London: King's College London, 1993), 69-100.

${ }^{67}$ Die Urkunden Karls III, ed. P. Kehr, MGH Diplomata Regum Germaniae ex Stirpe Karolinorum 2 (Berlin: Weidmann, 1937), no. 64; MacLean, Kingship and Politics, 157-8, 199-229.

${ }^{68}$ Die Urkunden Karls III., no. 109. On the same visit he also had an eternal flame lit for his own soul in the Regensburg chapel; no. 107. Both chapels were dedicated to the Mother of God.

${ }^{69}$ Recueil des actes de Charles III le Simple, nos 90-1. The heavily dynastic narrative of these charters (on which see Airlie, "Palace of Memory", 16-17) is notable. Die Urkunden Arnolfs, ed. P. Kehr, MGH Diplomata Regum Germaniae ex Stirpe Karolinorum 3 (Berlin, 1940), no. 31, Arnulf's only charter for Aachen, was issued from Frankfurt ("palatium regale"). Die Urkunden Lothars I. und Lothars II., ed. T. Schieffer, MGH Diplomata Karolinorum 3 (Berlin and Zurich, 1966), Lothar I no. 136, also reminisces about Charlemagne's founding of Aachen.
} 
kingdoms in an imaginary network. ${ }^{70}$ Aachen was the generator at its heart, its charisma drawn on through invocation or association even though it was rarely visited, far less used as a seat of government.

The fact that Aachen in the decades around 900 was simultaneously central (symbolically) and peripheral (practically) means that it was not a straightforward matter for the Ottonians to assume its control. The break in its history in the late ninth century, which was perceived by contemporaries, meant that it was not simply sitting there waiting to be inherited by the next royal dynasty that managed to establish itself, and its place in the political geography of post-Carolingian Europe was necessarily altered. Although the palace is generally seen as one of the three main centres of the early Ottonian Reich, in fact the first two Saxon kings went there comparatively rarely: Henry I and Otto I visited Aachen only nine times in total between 925 and 973, with the average time spent there on each occasion being surprisingly short (barely more than in the areas categorised by Müller-Mertens as "transit zones"). ${ }^{71}$ Nor were these visits regularly spaced: six of the nine visits took place in the period 944-51, with the others falling in 930, 936 and $966 .{ }^{72}$ What is more, when Otto was there he only issued charters for Lotharingian recipients, which suggests that in his reign Aachen was closely linked to regulation of the region in which it lay rather than a nodal point from which the whole kingdom could be ruled. ${ }^{73}$

Far from demonstrating "how firmly Lotharingia was integrated into the east Frankish realm under Otto I", I think the explanation for this pattern of visits to Aachen lies in the problems he had in asserting his control of the region in the face of opposition from rivals to the west. ${ }^{74}$ The timing of the first two visits suggests that they were opportunistic attempts to take advantage of rivals' momentary weakness: Henry I formally gained control of Aachen in 925 but did not venture there until shortly after Charles the Simple's death in captivity in late 929; while Otto's choice of Aachen for his coronation in 936 is perhaps best seen as a response to the coronation of Charles's young

\footnotetext{
${ }^{70}$ Quotation ("Dialog zwischen zwei Pfalzorten") from Zotz, "Symbole der Königsmacht", 368, where Ottonian examples are discussed.

${ }^{71}$ The data is mapped and discussed by Müller-Mertens, Reichsstruktur; Müller-Mertens, "Verfassung des Reiches", 194; Streich, "Palatium als Ordnungsbegriff", 104.

${ }^{72}$ Falkenstein, Otto III. und Aachen, 27-9 lays out the evidence.

${ }^{73}$ The map in Müller-Mertens, "Verfassung des Reiches", 196, illustrates this.

${ }^{74}$ Quotation from Falkenstein, Otto III. und Aachen, 30.
} 
son Louis IV in west Francia only weeks earlier. ${ }^{75}$ Charters issued around the time of these two visits suggest an attempt by the east Frankish kings to appropriate the essence of Aachen by inserting themselves rhetorically into an unbroken tradition of Frankish kingship - but we may wonder whether this reflected a desire to emulate Charlemagne directly so much as a competitive reaction to the promiscuous discourse of Carolingianness that had been deployed by Charles the Simple against his nonCarolingian rivals, and which Louis showed signs of resuming. ${ }^{76}$ Louis openly maintained a claim to Lotharingia, which had been part of his father's kingdom, and even invaded in 939-40. The west Frankish kings never definitively dropped these claims, though they were put on the back-burner after 946 when Louis became indebted to Otto for rescuing him from his internal enemies. It is surely no coincidence that the major concentration of Ottonian visits to Aachen fell in the years either side of 950, precisely when Louis was at his weakest and most beholden to Otto. These circumstances led to an intensification of contact between the kingdoms in the later 940s, and indeed we know that there were west Frankish representatives present at almost all of Otto's residencies in Aachen. No doubt these meetings helped emphasise Otto's superiority over the weakened western ruler, but the fact that his ambassadors were present during these visits may have also been intended to help Louis save face in light of his apparent capitulation over the Lotharingian question.

But in any case, this flurry of regular association with Aachen was the exception rather than the norm, as indicated by Otto's attempt to visit the palace at Easter 953 which was aborted after he discovered the locals unwilling to receive him properly. ${ }^{77}$ This rejection took place as a rebellion was brewing in Lotharingia, the course of which provides some evidence that neither Otto nor his agents had much say in the north of the region, where local aristocrats and members of the west Frankish royal family are instead found battling for influence. It would be another fifteen years - January 966 - before Otto paid his next (and last) visit to the palace, describing it, in a charter dripping in dynastic rhetoric and nods to the legacy of Charlemagne, as "the most important royal seat this

\footnotetext{
${ }^{75}$ T. Reuter, Germany in the Early Middle Ages c. 800-1056 (London: Longmans, 1991), 148.

${ }^{76}$ Charters: Die Urkunden Heinrichs I., no. 23; Die Urkunden Ottos I., no. 1. Choice of Aachen as imitation of Charlemagne: Bernhardt, Itinerant Kingship, 4. Louis IV and the Carolingian past: above, n. 48, and Schneidmüller, Karolingische Tradition, 147-56; Koziol, Politics of Memory, 252-9, 294-306.

${ }^{77}$ Adalbert, Continuatio, s.a. 953, 166-7; Widukind, Rerum Gestarum Saxonicarum Libri Tres, $3.14,111$.
} 
side of the Alps". ${ }^{78}$ Even this apparently clear designation should not be interpreted as a timeless statement about Ottonian political geography, but rather as the product of a particular set of circumstances, defined by the re-establishment of a state of formal truce between the eastern and western courts and by the death of Otto's brother Brun (the duke of Lotharingia), both in $965 .^{79}$ Otto's arrival in the area in late 965 to "arrange all the affairs of the Lotharingian kingdom as he deemed suitable", though it was proclaimed in an imperial register, was primarily a reaction to these local events, and his charter's elaborate comments about Aachen and Charlemagne may reflect the fact that this unusually intrusive intervention in a region where the king was rarely seen required unusually high-pitched levels of justification. ${ }^{80}$ It is possible that one version at least of Widukind's Deeds of the Saxons (the main narrative source for Otto's reign) was a product of this same moment, which may give a context for that text's famously elaborate depiction of Otto's allegedly Carolingian-style coronation at the "palatium" of Aachen. ${ }^{81}$ But even now, with the competition on the back foot and the king (for once) on the spot to call the shots himself, the Ottonian court struggled to assert itself in the region: a royal charter of the same period bemoans Otto's lack of resources in "those parts". 82 And when Otto II stayed at Aachen following his father's death in 973, a contemporary author from Alemannia described him as residing "in the remotest corner of his kingdom."

It seems, then, that the undeniable political symbolism associated with Aachen was not a resource that the Ottonian kings could use at will, precisely because the inflation of the palace's symbolic significance coincided with its move from the royal heartlands to the geographical peripheries of the post-Carolingian kingdoms. Kings like Charles the Bald and Charles the Fat, operating within the high Carolingian hegemony of

\footnotetext{
${ }^{78}$ Die Urkunden Ottos I, no. 316: "hoc palatium precipua cis Alpes regia sedes". For another analysis of this document see Zotz, "Symbole der Königsmacht", 363-6. Otto was probably not present at his son's coronation at Aachen in 961, but even if he had been it is significant that this followed an earlier coronation at Worms which Lotharingian magnates had not attended - hardly a sign that they were at the king's beck and call: Adalbert, Continuatio, s.a. 961, 171; Müller-Mertens, Reichsstruktur, 131-2.

${ }^{79}$ I will give full details of this argument elsewhere. Contrast Regino, Chronicle, s.a. 869, 98 (an early tenth-century source) whose description of Aachen as a sedes regni refers to its status within Lotharingia, not the Carolingian territories writ large.

${ }^{80}$ Quotation from Adalbert, Continuatio, s.a. 966, 177. The argument for a correlation between ideological statements and political intrusiveness is made by Reuter, "Regemque", 132-3.

${ }^{81}$ Widukind, Rerum Gestarum Saxonicarum Libri Tres, 2.1, 63-6.

${ }^{82}$ Die Urkunden Ottos I., no. 322.

${ }^{83}$ Gerhard, Vita S. Oudalrici Episcopi, ed. G. Waitz, MGH SS 4 (Hanover: Hahnsche, 1841), c. 28, 415-16;

K. Leyser, “Ottonian Government”, English Historical Review 96 (1981), 721-53, at 750-1.
} 
the later ninth century, had been able to appropriate the resonance of their ancestral palace effortlessly and remotely - nobody could doubt that Carolingian kings had a stake in this most Carolingian of places. But the royal protagonists of the post-Carolingian world belonged to rival dynasties, meaning that Aachen became a site of competition, a contested inheritance wrapped up in a cold war for northern Lotharingia that lingered on until the 980s. Kings like Charles the Simple, Henry I and Otto I certainly laid claim to the palace, partly by asserting its character as a "palatium", an intrinsically royal site, but in contrast to their ninth-century predecessors seem only have been able to do so by actually being there. Their attempts to assume possession of the palace were anything but effortless, and it was only in brief windows such as the late 940s or mid-960s that circumstances permitted Otto and his circle to flaunt narratives which situated their possession of Aachen in a longer historical continuum stretching back to Charlemagne. The sentiment expressed in Otto's charter of January 966 about the pre-eminence of Aachen north of the Alps was later picked up by his grandson Otto III, who fetishised the palace and sought to associate himself explicitly with Charlemagne, even going so far as to exhume and rebury him in the year 1000. But Otto III operated in a very different environment from his predecessors, facing no serious competition for Lotharingia after 987. The ossification of Aachen's primacy was not a simple consequence of Ottonian reverence for the old emperor, far less a sign of simple continuity from the old regime - it was shaped at least as much by the tenth-century cold war for northern Lotharingia during which the palace's symbolic meaning was insisted upon by kings seeking a rhetorical toehold to help them cling onto their fragile grip on the region. The symbolism of the place was kept alive and cranked up precisely because it was competed over by kings who were unable to control it. Post-Carolingian kings needed to classify such places, to constantly recreate and reappropriate their royalness, in order to possess them and to stop their "sacredness" succumbing to mundanity. ${ }^{84}$ Not just as a metonym for the kingdom, but also as a quality of place, the concept of palace-ness was an idea that had to be actively renewed if it was to remain relevant to the political geography of the realm.

\footnotetext{
${ }^{84}$ My wording here refers to the discussion of Smith, "Elementary Forms". Contrast the case of Compiègne, whose identity as a palace gradually gave way in the tenth and eleventh centuries to generic labels like "castrum" (stronghold): Bautier, "Les itineraires des souverains", 108-10.
} 


\section{Comparing the Ottonian itinerary}

One reason that early medieval rulers were so keen to lay claim to the permanence of royal palaces like Aachen was that kings themselves had to move around so much. ${ }^{85}$ If visiting Aachen can be seen not so much as a routine part of the pre-973 itinerary as a means by which Otto I asserted his right to control territory and tradition - if, in other words, it was as much an argument about political geography as a reflection of it - then we should ask whether this has any implications for the notion of the royal itinerary itself. The extent to which the meaning of particular sites influenced the movement of kings is sometimes left to one side in discussions of the royal progress, flattened by the seeming precision of categories such as "heartland", "periphery" and "transit zone". The itinerary is itself regarded as an institution by historians, and indeed as the unmistakeable fingerprint of Ottonian government, distinguishing it from its Carolingian predecessor and from other contemporary polities. The most influential judgement here is that of Karl Leyser, whose great 1981 essay on Ottonian government describes the itinerary as the dynasty's "most essential and carefully administered institution." the royal itinerary is now more or less taken for granted, and has recently been reified even further by attempts to transplant the Leyserian model of tenth-century Germany to late Anglo-Saxon England. ${ }^{87}$ Such is the centrality of the concept of itinerant kingship to current views of the tenth century that the term is often used as shorthand for a type of kingdom in which governmental institutions were weak and power was personal, and treated as inseparable from other political phenomena like the royal feast, hunt and assembly. ${ }^{88}$

Regarding such a package of phenomena as representative of a type of polity is not necessarily a problem, since ideal-types are useful. Nor is there any doubt that Ottonian kings (like all early European rulers) were mobile, and that there was some

\footnotetext{
${ }^{85}$ T. Martin, "Chronicling the Iberian Palace: Written Sources and the Meanings of Medieval Christian Rulers' Residences", Journal of Medieval Iberian Studies 2 (2010), 109-39, esp. 117.

${ }^{86}$ Leyser, "Ottonian Government", 746. See also Bernhardt, Itinerant Kingship, 46: "The royal progress itself became the major institution of government". The classic discussion is H. Peyer, "Das Reisekönigtum des Mittelalters", Vierteljahrschrift für Sozial- und Wirtschaftsgeschichte 51 (1964), 1-21.

${ }^{87}$ L. Roach, "Hosting the King: Hospitality and the Royal iter in Tenth-Century England", Journal of Medieval History 37 (2011), 34-46; though cf. the more systematic comparison by T. Zotz, "Kingship and Palaces in the Ottonian Realm and in the Kingdom of England", in England and the Continent in the Tenth Century, ed. C. Leyser, D. Rollason and H. Williams (Turnhout: Brepols, 2011), 311-30.

${ }^{88}$ E.g. Bernhardt, Itinerant Kingship, 49-52; Roach, "Hosting the King".
} 
planned regularity to their movements - witness the tenth-century custom of visiting certain churches and palaces at specific times of the year (for example Easter at Quedlinburg), or the clear expectation that they would be able to claim hospitality from churches and monasteries in their kingdoms. ${ }^{89}$ The concept only becomes unhelpful when the perceived institutional logic of the itinerary comes to be seen as sufficient explanation for particular political events, as in Falkenstein's argument that Otto I's visits to Aachen reveal an attempt to institutionalise a formal tradition of paschal journeys through northern Lotharingia. ${ }^{90}$ Moreover if we accept that, as Müller-Mertens puts it, "the centre of the realm was the travelling court", we are required to play down the significance of specific places to contemporary conceptions of political order. ${ }^{91}$ A certain amount of deconstruction is therefore in order, as a counterbalance to this tendency.

The notion of itinerant rulership is well served by a comparative perspective because it tacitly draws its force from a comparison, between kings "travelling and visiting different regions in turn" and those ruling from a "single permanent capital."92 These categories are generally seen as mutually exclusive, and sometimes even as sequential evolutionary stages. ${ }^{93}$ And the contrast that historians generally have in mind for itineracy is with "domination based on a fixed residence" as found in the political systems of the contemporary Byzantine and Muslim worlds. ${ }^{94}$ But while the applicability of the notion of the "royal capital" to the kingdoms of medieval Europe has been endlessly debated, the utility of its supposed antonym, itinerant kingship, has until recently attracted very little critical scrutiny. ${ }^{95}$ Comparing the tenth-century West with

\footnotetext{
${ }^{89}$ Brühl, Fodrum; Bernhardt, Itinerant Kingship.

${ }^{90}$ Falkenstein, Otto III. und Aachen, 28.

91 Müller-Mertens, "Verfassung des Reiches", 193: "Das Zentrum des Reiches war der reisende Königshof."

92 J.H.W.G. Liebeschuetz, "Ravenna to Aachen", in Sedes Regiae (ann. 400-800), ed. G. Ripoll López and J.M. Gurt (Barcelona: Reial Acadèmia de Bones Lletres, 2000), 9-30, at 28. See also C. Bowlus, "Mobility, Politics and Society in Medieval Germany", in German Literature of the High Middle Ages, ed. W. Hasty (Rochester, NY: Camden House, 2006), 277-89, at 277.

93 Brühl, "Remarques", 199-200; C. Ehlers, "Wie sich ambulante zu residenter Herrschaft entwickelt hat", in Die Macht des Königs. Herrschaft in Europa vom Frühmittelalter bis in die Neuzeit, ed. B. Jussen (Munich: C.H. Beck, 2005), 106-24.

${ }^{94}$ Leyser, "Ottonian Government", 746.

95 A notable exception is the very thought-provoking critique by R. McKitterick, Charlemagne: The Formation of a European Identity (Cambridge: Cambridge University Press, 2008), 171-97. On capitals see for example E. Ewig, "Résidence et capitale pendant le Haut Moyen Age", in E. Ewig, Spätantikes und fränkisches Gallien. Gesammelte Schriften 1 (Munich: Artemis, 1976), 362-408; Brühl, "Remarques";
} 
Byzantium, dominated by the city of Constantinople, would certainly validate the contrast, and shows it to be broadly useful. But we must remember that the emphatically metropolitan context of Byzantine court politics was very unusual in the Middle Ages and should not be taken as representative of capital-based government. ${ }^{96}$ Here, then, I would like to play devil's advocate by holding up some aspects of the representation of rulership in the Caliphate as a mirror to the dominant conception of the Ottonian itinerary as a distinctive institution.

It goes without saying that the Caliphate and the Reich were radically dissimilar in many ways, and comparing the movement of rulers in each highlights some obvious differences. For a start the Caliphate was much more urbanised and administratively centralised. There was also the matter of climate: patterns of movement in the Middle East were much more likely to be influenced by seasonal or environmental factors. And although palaces were sometimes associated with mosques, there is no equivalent in the Caliphate to the Ottonians' relationship with monasteries and other ecclesiastical institutions that they used for hospitality and to control strategic routes. ${ }^{97}$ This distinction translated into the representation of rulership: whereas Western rulers were idealised as builders of churches, their counterparts in the Muslim world were flattered as founders of cities; and while Carolingian and Ottonian rulers often appropriated the palaces of their predecessors, caliphs were more usually credited with constructing their own residences from scratch, albeit often near to existing centres. ${ }^{98}$ The difference in representation reflects the much greater wealth of the Umayyad and Abbasid elites compared to those of the West. But it also reminds us of the different historiographical traditions of the two cultures: historians in the tenth-century West, unlike those in the Middle East, were more likely to be religious professionals.

Given the fact that our European sources were often written by churchmen (and women) with direct experience of supporting the king as he moved through their area, it is perhaps surprising that they rarely identified the royal itinerary as such. Although

Sedes Regiae, ed. Ripoll López and Gurt; D. Keene, "Ideas of the Metropolis", Historical Research 84 (2011), 379-98.

${ }^{96}$ P. Magdalino, "Court and Capital in Byzantium", in Royal Courts in Dynastic States and Empires. A Global Perspective, ed. J. Duindam, T. Artan and M. Kunt (Leiden and Boston: Brill, 2011), 131-44.

${ }^{97}$ Hillenbrand, Islamic Architecture, 83; G. Fowden, Qusayr Amra: Art and the Elite in Late Antique Syria (Berkely and Los Angeles: University of California Press, 2004), 282-3.

${ }^{98}$ Hillenbrand, Islamic Architecture, 378-9; Fowden, Qusayr Amra, 143. 
numerous chronicles, letters and charters provide information on the logistical infrastructure which underpinned the travels of the royal court and allow us to infer the patterns of movement that helped shape early medieval political life, they do not explicitly identify the itinerary as an institution in itself. The expression iter regis, which is commonly used by historians as if it were a technical term for the institution of the itinerary, is actually vanishingly rare in the sources. ${ }^{99}$ By contrast, rulers' itineraries are identified as specific institutions in other cultures, such as fourteenth-century Java whence we have a poem describing a royal progress which reifies the movement of the king to such an extent that the author states that "the whole of Java is to be as the capital of the king's realm." 100 Closer to home, Tabari reports a speech made by the mother of a ruler from Ferghanah in which she listed the six essential characteristics of a king, the last of which was possession of "a storehouse sufficient to live off no matter where in the world he takes it."101

It is true that Western annalists frequently recorded where the king spent Easter and Christmas, but this historiographical reflex (which suggests a desire to show a connection between secular events and the religious calendar) is also found in the East, where Tabari ended his "annalistic" entries by stating which member of the ruling dynasty had led the Hajj that year. And although the sources make it clear that postCarolingian rulers were ceaseless movers, in the eyes of tenth-century historians like Widukind of Corvey or Flodoard of Rheims the king tended to disappear over the horizon when he left Saxony or Francia respectively; these writers did not perceive the political centre of the realm as infinitely mobile, constituted only in the spotlight surrounding the king, but instead regarded their own milieus as central, permanent and immovable. Indeed, the best-known early medieval description of itinerant kingship per se values it negatively - Einhard's famous description of the last Merovingians (the kings deposed by the Carolingians) as moving from place to place on "a cart pulled by yoked oxen and led by a cowherd in the country manner." ${ }^{\prime 102}$ This is strikingly similar to one of Tabari's

\footnotetext{
${ }^{99}$ Based on basic searches in the MGH and PL databases.

${ }^{100}$ Geertz, "Centers, Kings and Charisma”, 129-34. In the same article (134-42) Geertz discusses similar sentiments concerning the rulers of nineteenth-century Morocco.

${ }^{101}$ The History of Al-Tabari vol. 26: The Waning of the Umayyad Caliphate. Prelude to Revolution, AD 738-745, trans. C. Hillenbrand (Albany: SUNY Press, 1989), 34.

${ }^{102}$ Einhard, Vita Karoli, c. 1, p. 3; trans. Ganz, Two Lives, 19.
} 
comments about the late Umayyad caliph Walid II, an exact contemporary of the last Merovingians: "he began to dislike places where there were people ... he kept on moving about and going out hunting, and he distressed the people and his soldiers."103 These statements of Einhard and Tabari are highly ideological, intended to contrast the rusticity and mobility of an old dynasty with the civility and stability of the rulers who deposed them. $^{104}$

This representational similarity reminds us that, for all the self-evident differences between the Frankish and Muslim worlds, they both had dynastic political systems, and place played an important role in dynastic competition. Thus for example we have inscriptions and elaborate picture cycles at two residences owned by Walid II before he became Caliph, which were intended to advertise his claims to the succession (against those of his cousins). ${ }^{105}$ This attempt to categorise his own possessions as innately royal recalls the late Carolingians rebranding their itineraries by selectively applying the term "palatium" to different residences, and Otto I attempting the same at Magdeburg - in each case we see rulers attempting to assert the public political nature of centres with which they were personally associated.

The symbolic character conferred on his remote desert palaces by Walid II was all the more visible at such major centres as Baghdad and Damascus, which are commonly imagined as representing a type of site - the capital - alien to the early medieval West. Nonetheless, basic parallels can be identified. Baghdad's centrality was exported and reproduced, like Aachen's, through architectural imitation in the construction of new palaces in other parts of the Caliphate. ${ }^{106}$ Even when the "capital" itself moved, as when Charlemagne's contemporary Harun al-Rashid established al-Raqqa in Syria as his main

\footnotetext{
${ }^{103}$ The History of Al-Tabari vol. 26, 127.

${ }^{104}$ Walid II was a particular target for retrospective defamation by Abbasid writers: The History of AlTabari vol. 26, XIII-XIV. On the widespread Western stereotype about the superiority of the settled to the pastoral see R. Bartlett, "Heartland and Border: the Mental and Physical Geography of Medieval Europe", in Power and Identity in the Middle Ages. Essays in Memory of Rees Davies, ed. H. Pryce and J. Watts (Oxford: Oxford University Press, 2007), 23-36. The desert was a value judgement as much as a location: The History of Al-Tabari vol. 26, 80-1 depicts the Caliph Hisham retreating to the desert before letting slip that he was actually resident in a Byzantine city.

105 A. Marsham, Rituals of Islamic Monarchy. Accession and Succession in the First Muslim Empire (Edinburgh: Edinburgh University Press, 2009), 126-8; Fowden, Qusayr Amra, 175-96.

106 The History of Al-Tabari vol. 28: Abbasid Authority Affirmed, trans. J.D. McAuliffe (Albany: SUNY Press, 1995), 244-5; H. Kennedy, The Prophet and the Age of the Caliphates: the Islamic Near East from the Sixth to the Eleventh Century (London and New York: Longman, 1986), 136.
} 
residence, the notion of Baghdad as the centre of the realm persisted. On returning from a visit to the distant eastern province of Khurasan in late 805 Harun travelled back to alRaqqa via Baghdad. Though he did not even stay there overnight he was careful to stage a demonstrative political act as he passed, displaying mastery over his dynasty by burning the body of his sister's fiancé, who had disobeyed him, on a bridge. The brief stop also generated a burst of historiographical activity on which Tabari drew, relating a speech that the Caliph was reputed to have made to one of his commanders in which he described Baghdad as a great "seat of power" and as his home (which it clearly was not) and that of his forefathers. He also excused his departure for al-Raqqa as prompted by his need to keep rebels in check: "If it were not for that, I would never leave Baghdad or set foot out of it as long as I lived." A poem written on the same occasion dwelled on the idea that Harun had neither really stopped nor started his journey at Baghdad, and therefore tried to imply that he was, paradoxically, always there. ${ }^{107}$ The late Umayyad capital at Damascus had had a similar aura for those who wished to wield power at the political centre. When, for example, Walid II needed to advertise his acquisition of the Caliphate in 743 he came to Damascus to receive the oath of allegiance, even though he had spent almost his entire career away from the city. By the same token, when Yazid III deposed Walid a year later, he did so not by capturing or killing his opponent, but by successfully riding into Damascus on an ass, though the Caliph himself was not there. ${ }^{108}$

In these two instances we do not see the capitals of the Caliphate acting as practical centres of rulership, for at these moments the rulers in question were permanently absent from them. But the cities nonetheless remained vital as stages for acts of symbolic communication by which rulers asserted their legitimacy and authority - in other words their very right to be regarded as rulers. They may have been administrative centres, but the pull they exerted was symbolic as well as bureaucratic. These Caliphs' need to advertise their association with such centres lay partly in the fact that their grasp on them was weak - the pattern of his earlier career meant that Walid II had little support in Damascus, and although the real reasons for Harun's move to Syria are not clear, some

${ }^{107}$ The History of Al-Tabari vol. 30: The Abbasid Caliphate in Equilibrium, trans. C.E. Bosworth (Albany: SUNY Press, 1989), 256-7.

${ }_{108}$ The History of Al-Tabari vol. 26, 141-8; G. Hawting, The First Dynasty of Islam. The Umayyad Caliphate AD 661-750 (London and Sydney: Croom Helm, 1986), 90-4. 
Caliphs of that era are known to have felt insecure in Baghdad. ${ }^{109}$ These were places whose political meanings made them all-encompassingly significant but which in terms of political geography could sometimes become peripheral, so that even when they could not be used as seats of rule, rulers had to somehow possess them. Narratives and traditions clung doggedly to particular locations, often outlasting the specific political configurations that had given rise to them in the first place. The patterns of movement that we see here, and in post-Carolingian Europe, were shaped not just by governmental practicalities, nor by the internal institutional logic of royal itineracy, but also by the meanings of places and, in aggregate, the "representative landscape" of the realm. ${ }^{110}$

The comparison is in many ways superficial: Harun and Walid were not typical Caliphs; post-Carolingian kings did not control an administrative structure based at particular locations; and rebranding the Abbasids as itinerant rulers would hardly be accurate. But probing the supposed opposition itinerary / capital helps remind us that just as the Caliphate was not simply a rigidly-defined structure of capitals and provinces, the Ottonian kingdom need not only have existed within the spotlight that followed the king round his kingdom. The concept of "itinerant kingship" as shorthand for a kind of polity based on features such as the ruler's presence, ritualised solemnities, hunting and feasting is not as useful as it seems because such features were also crucial to the conduct of politics in much more bureaucratised systems like the Caliphate. The image of the relentlessly mobile Ottonian king, moving from place to place and scattering Weberian charisma behind him like the tail of a comet, is perhaps not quite so singular: the conceptual opposition between a single static centre and a forever mobile royal court obscures what these polities had in common. ${ }^{111}$ The contrast of types remains useful, especially were we to compare purer examples of itinerant kingships such as Geertz's

${ }^{109}$ Kennedy, Court of the Caliphs, 66-7, 202; A. Northedge, The Historical Topography of Samarra (London: British School of Archaeology in Iraq, 2005), 247.

${ }^{110}$ See Reuter, "Regemque", 141, for this expression.

${ }^{111}$ The opposition between charismatic and bureaucratic rule is sometimes posed too starkly: see E. Shils, "Charisma, Order and Status", American Sociological Review 30 (1965), 199-213; C. West, "Unauthorised Miracles in Mid-Ninth-Century Dijon and the Carolingian Church Reforms", Journal of Medieval History 36 (2010), 295-311, at 308-10; Roach, "Hosting the King", 45. On the co-existence of itineracy and administrative government in the Central Middle Ages see B.F. Reilly, The Kingdom of Léon-Castilla under King Alfonso VI, 1065-1109 (Princeton: Princeton University Press, 1988), 148-57; R.J. Bartlett, England Under the Norman and Angevin Kings, 1075-1225 (Oxford: Oxford University Press, 2000), 13343 (also pointing out that mobile and sedentary rule need not be seen as mutually exclusive). 
Java with more emphatically metropolitan empires such as Byzantium. But in between we see a spectrum of polycentric realms whose centres had a range of shifting meanings which affected the way rulers interacted with them. Itineracy was less a coherent system of rule, drifting free of institutional moorings in a swamp of statelessness, than a habit of movements between highly symbolic but immobile centres - the destination mattered more than the journey. ${ }^{112}$

\section{Conclusion}

This article has hardly provided a comprehensive account of perceptions of the palace after 888, nor (given the primary focus on east Francia / Lotharingia) should its claims be thought necessarily to apply equally across all parts of the former empire. But because they helped articulate the notion of Carolingian order, focus on palaces does at least show us a corner of a bigger picture, and illuminates some of the texture of post- 888 politics. Although 888 was a before-and-after moment in the "patterned mess" of history, debates about change and continuity are not really adequate to describe the nature of the transition. ${ }^{113}$ Continuity, indeed, is a problematic concept for historians, and can easily melt into a denial of change which misrepresents the dynamism of all political history, including that of the early Middle Ages. Asking whether political institutions and the notion of a "state" survived or did not survive the disintegration of the empire only gets us so far because those categories are potentially anachronistic. Tracking contemporary perceptions of the palace gives a different perspective, showing us a world in which symbols of political order survived not as a vague or passive adaptation of Carolingian traditions, but as part of active struggles to instrumentalise the Carolingian past in pursuit of immediate political goals. This was a world where cores and peripheries had been inverted, in which the location of the political centre had become insecure, disputed, and subject to constant change, and in which the "palatium", where concepts of geography and order coincided, became a site where claims about the relationship of past and present were loaded with tension - the world of Notker of St-Gall and Regino of Prüm,

\footnotetext{
112 These comments echo those of R. McKitterick, "A King on the Move: the Place of an Itinerant Court in Charlemagne's Government”, in Royal Courts, ed. Duindam, Artan and Kunt, 145-69, esp. 166-7.

${ }^{113}$ For "patterned mess" see M. Mann, The Sources of Social Power. Volume 2: The Rise of Classes and Nation States, 1760-1914 (Cambridge: Cambridge University Press, 1992), 4.
} 
who saw the predictable past coming to a certain end and looked anxiously into a future full of doubt. When a new European hegemony gradually emerged from the military successes of Otto I in the 940s and 950s, post-Carolingian geography acquired a sense of solidity, with a new confidence in the shape of the political order reflected in the revival of large-scale historical writing in circles surrounding the court in the 960s. But the Ottonian order of the later tenth century was not an alternative package of norms and structures which simply appeared to fill a vacuum left by the vanished institutions of the Carolingian Empire, nor did it represent a modified perpetuation of those institutions. Rather, it was something that was dynamically and accidentally created by the competition for power and legitimacy which took place in the five or six decades after 888..$^{114}$

\footnotetext{
${ }^{114}$ For valuable comments on earlier versions of this article I am grateful to Stuart Airlie, Tim Greenwood, Matt Innes, Ruth Macrides, Jinty Nelson and Jens Schneider. For feedback and discussion I also thank the other members of the Diverging Paths group, and seminar audiences at the universities of Edinburgh and Tübingen.
} 